GRASAS Y ACEITES 71 (4)

October-December 2020, e378

ISSN-L: 0017-3495

https://doi.org/10.3989/gya.0342191

\title{
Diazole and triazole derivatives of castor oil extract: synthesis, hypoglycemic effect, antioxidant potential and antimicrobial activity
}

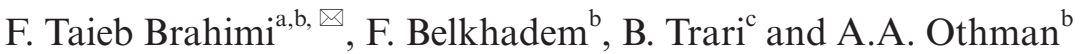 \\ ${ }^{a}$ Département de classe préparatoire, Ecole Supérieure en Génie Electrique et Energétique d’Oran, \\ Bp. 64 CH2 Achaba Hanifi USTO 31003 Oran, Algérie. \\ ${ }^{\mathrm{b}}$ Laboratoire de Synthèse Organique Bioactive, Département de Chimie Organique Industrielle, \\ Faculté de Chimie, Université des Sciences et de la Technologie d'Oran, Mohamed Boudiaf-USTO-MB, \\ BP. 1505, El-M'naouer, 31003 Oran, Algérie. \\ ${ }^{\mathrm{c}}$ Laboratoire scientifique et technique régional de police ORAN 31000, Algérie. \\ ${ }^{\otimes}$ Corresponding author: fawziatb@yahoo.fr
}

Submitted: 16 March 2019; Accepted: 08 October 2019; Published online: 22 October 2020

SUMMARY: The ricinoleate triglyceride was extracted from castor-oil seeds grown in Algeria and isolated by catalytically methanolyse to methyl ricinoleate. Six diazole and triazole derivatives of ricinoleic acid were synthesized and characterized: 1,3,4-oxadiazole-5-thione (4); 1,3,4-thiadiazole-5-thione (5); 4-N-amino-1,2,4-triazole-5-thiol (7); 1,2,4-triazole-5-thione (9); 5-amino-1,3,4-oxadiazole (10) and 5-amino-1,3,4-thiadiazole (11). The antibacterial and antifungal screening data of synthesized compounds showed appreciable inhibition and among them, 5, 7 and 8 showed more inhibition on Gram positive Enterococcus faecalis than reference ampiciline; while compounds 1, 7, 8,10 and 11 showed competitive antifungal effects compared to reference amphotericin B. In addition, all synthesized compounds (1-11) showed competitive antioxidant properties, particularly compounds 7 at 125, 250, 500 and $1000 \mu \mathrm{g} / \mathrm{mL}$ and compounds 4, 5 and 9 at a concentration of $1000 \mu \mathrm{g} / \mathrm{mL}$. The intermediate compounds 1,2 and 8 showed anti- $\alpha$-amylase activity at various concentrations in the range of $\mathrm{IC}_{50}=(120.25 \pm 1.17-130.42 \pm 2.48)$. Oxadiazole 4 showed the best $\alpha$-amylase inhibition by $78.5 \%$ at a concentration of $1000 \mu \mathrm{g} / \mathrm{mL}$.

KEYWORDS: Anti diabetic; Antimicrobial; Antioxidant; Castor oil; Extraction; Heterocycle

RESUMEN: Diazoles y triazoles derivados del extracto de aceite de ricino: síntesis, efecto hipoglucémico, potencial antioxidante y actividad antimicrobiana. Los triglicéridos de ricinoleico se extrajeron de semillas de aceite de ricino cultivadas en Argelia y se sintetizó catalíticamente con metanolisis el ricinoleato de metilo. Seis derivados de diazoles y triazoles de ácido ricinoleico se han sintetizado y caracterizado: 1,3,4-oxadiazol-5-tiona (4), 1,3,4-tiadiazol-5-tiona (5), 4-N-amino-1,2,4-triazol-5-tiol (7), 1,2,4-triazol-5-tiona (9), 5-amino-1,3,4-oxadiazol (10) y 5-amino-1,3,4-tiadiazol (11). Los datos de detección antibacteriana y antifúngica de los compuestos sintetizados mostraron una inhibición apreciable, entre ellos, los compuestos 5, 7 y 8 mostraron más inhibición en Enterococcus faecalis Gram positivo que la ampicilina de referencia. Mientras que los compuestos 1, 7, 8, 10 y 11 mostraron una influencia antifúngica competitiva en comparación con la anfotericina de referencia $\mathrm{B}$. Como todos los compuestos sintetizados (1-11) mostraron propiedades antioxidantes competitivas, particularmente los compuestos 7, a 125, 250, 500 y $1000 \mu \mathrm{g} / \mathrm{mL}$ también compuestos 4, 5 y 9 a una concentración de $1000 \mu \mathrm{g} / \mathrm{mL}$. Los compuestos intermedios 1,2 y 8 mostraron actividad anti- $\alpha$-amilasa a diversas concentraciones en el rango de IC50 $=(120.25 \pm 1.17-130.42 \pm 2.48)$. El oxadiazol 4 mostró la mejor inhibición de la $\alpha$-amilasa en un $78.5 \%$ a una concentración de $1000 \mu \mathrm{g} / \mathrm{mL}$.

PALABRAS CLAVE: Aceite de ricino; Antidiabético; Antimicrobiano; Antioxidante; Extracción; Heterociclo

ORCID ID: Taieb Brahimi F https://orcid.org/0000-0002-9460-8193, Belkhadem F https://orcid.org/0000-0002-7113-7798, Trari B https://orcid.org/0000-0001-7997-3638, Othman AA https://orcid.org/0000-0001-8116-4506

Citation/Cómo citar este artículo: Taieb Brahimi F, Belkhadem F, Trari B, Othman AA. 2020. Diazole and triazole derivatives of castor oil extract: synthesis, hypoglycemic effect, antioxidant potential and antimicrobial activity. Grasas Aceites 71 (4), e378. https://doi.org/10.3989/gya.0342191

Copyright: (C2020 CSIC. This is an open-access article distributed under the terms of the Creative Commons Attribution 4.0 International (CC BY 4.0) License. 


\section{INTRODUCTION}

Castor oil is a natural production of the castor plant (Ricinus Communis) (Mubofu, 2016). Castor oil plants are widespread throughout the globe, particularly in tropical regions such as India, the southeastern Mediterranean Basin of North Africa (Trochain, 1930), Los Angeles, California (Witchard, 1997) and elsewhere. Castor oil has many uses; for example, it remains of commercial importance as a non-freezing, antimicrobial, pressure-resistant lubricant for special purposes, either for latex or metals, or as a lubricating component in fuels (Imankulov, 2012). Castor oil has long been used on the skin to prevent dryness. Whether pure or processed, it is still a component of many cosmetics (Bianchi et al., 2011; Rachapudi et al., 2017).

The high percentage of ricinoleic acid residues in castor oil and their derivatives inhibit virus, bacteria or fungi (Ghosh et al., 2013). The literature has revealed several synthetic modifications and utilization of ricinoleic acid. These modifications vary between ethylenic bond (Godard et al., 2013) hydroxyl group (Thames et al., 2006) and carboxylic acid group (Dutta et al., 2011; Lavanya et al., 2012).

Heterocyclic-fatty acid hybrids such as oxadiazole, thiadiazole and triazole derivatives of vegetable oils are a new class of fatty acid derivatives with a wide range of biological activities and significance in the field of medicinal chemistry. They possess a broad spectrum of therapeutic uses such as analgesic, antimicrobial, anti HIV activity, antitumor, antimalarial, anticancer, anticonvulsant, anti-diabetic, antioxidant (Cao et al., 2014; Ahmad et al., 2017).

This work is mainly concerned with the extraction of castor oil from seeds of the plant and the isolation of ricinoleic acid. The latter was subjected to synthetic modifications focused on the carboxylic group to ultimately give six diazole derivatives. The synthetic intermediates and final products were studied to determine the biological evaluation of their $\alpha$-amylase inhibitory, antimicrobial and antioxidant activities.

\section{MATERIALS AND METHODS}

\subsection{General}

All reactions were monitored by TLC, silica gel F254, made by Merck, Germany. Melting points $\left({ }^{\circ} \mathrm{C}\right)$ were measured in open glass capillaries using a Branstead 9001 Electrothermal melting point apparatus and were not corrected. The UV visible electron spectroscopy was recorded on an Optisen View 4.2 spectrometer. The IR spectra were recorded using $\mathrm{KBr}$ disks in a GENESISIIFTIR spectrophotometer, in $v$ units of $\mathrm{cm}^{-1}$. The ${ }^{1} \mathrm{H}$ and ${ }^{13} \mathrm{C}-\mathrm{NMR}$ spectra (1D) were recorded on a Bruker AC 400 $\mathrm{MHz}$ spectrometer (University of Lyon 1, France) in DMSO- $\mathrm{d}_{6}$ and referenced to TMS. Symbols $\delta$ were used for chemical sifts in ppm, $\mathrm{s}=$ singlet, $\mathrm{d}=$ doublet, $\mathrm{dd}=$ double doublet and $\mathrm{m}=$ multiplets. Mass spectra were obtained using a GC-MS CLARIS 500 (Laboratoire Régional de Police Scientifique d'Oran, Algeria). The microorganisms in this study were supplied and identified by the laboratory of microbiology by the university hospital of Oran1. The Mueller Hinton medium was supplied by (Difco).

\subsection{Chemistry}

\subsubsection{Oil extraction}

The castor oil (1) was extracted with a soxhlet extractor. Hexane (1L) and ground castor beans $(200 \mathrm{~g})$ were packed into a filter paper thimble. The extraction lasted $10 \mathrm{~h}$. The crude oil was treated with hot water to remove gums, hydrates, phosphates and other impurities and then it was neutralized with $0.1 \mathrm{~N} \mathrm{NaOH}$ to remove free fatty acid and soap to give castor oil (1), (84 g, 40.2\%) (Nakarmi et al., 2014). UV ( $\left.\lambda_{\max }\right)$ nm: 205; 210. IR $\left(\mathrm{CCl}_{4}\right), v \mathrm{~cm}^{-1:} 3452.92(\mathrm{OH}) ; 3008(\mathrm{CH}$ unsaturated); 2925,2855 (alkyl groups); 1742.37(C= O). ${ }^{1} \mathrm{H}$ NMR (400 MHZ, DMSO d $\left.\mathrm{d}_{6}\right) \delta(\mathrm{ppm}): 5.37-5.34(\mathrm{~m}, 6 \mathrm{H}$, $\left.\mathrm{CH}_{\text {alkenes }}\right) ; 5.19-5.14\left(\mathrm{~m}, 1 \mathrm{H}, \mathrm{C}-\mathrm{H}_{\beta}\right) ; 4.34(\mathrm{dd}, 2 \mathrm{H}$, $\mathrm{C}-\mathrm{H} \alpha) ; 4.10(\mathrm{dd}, 2 \mathrm{H}, \mathrm{C}-\mathrm{H} \gamma) ; 3.40(\mathrm{~s}, 3 \mathrm{H}, 3 \mathrm{OH})$; $2.06\left(\mathrm{~m}, 6 \mathrm{H}, \mathrm{OCOCH}_{3}\right) ; 2.24-1.50(\mathrm{~m}, 96 \mathrm{H}, \mathrm{CH}$ paraffinic); $0.82\left(\mathrm{~m}, 9 \mathrm{H}, \mathrm{CH}_{3}\right.$ terminal). ${ }^{13} \mathrm{C}$ NMR (400 MHZ, DMSO d $\left.{ }_{6}\right) \delta$ ppm: 172.13; 132.1; 126.5; $79.1 ; 69.8 ; 68.9 ; 61.6 ; 39.9 ; 39.7 ; 39.4 ; 39.1 ; 38.8$; $36.5 ; 35.1 ; 33.2 ; 31.4 ; 29.1 ; 29.0 ; 28.7 ; 28.6 ; 28.5$; $26.3 ; 26.2 ; 22.10 ; 13.80$.

\subsubsection{Methyl ricinoleate (2). Transesterification reaction}

The extracted oil (1) (25g; $0.028 \mathrm{~mol})$ was kept in three necked round-bottom flasks and heated to $65{ }^{\circ} \mathrm{C} . \mathrm{NaOH} / \mathrm{MeOH}(2,5 \mathrm{~g} / 20 \mathrm{~mL})$ were added with the aid of stirring and the mixture was heated for three hours (Akhabue et al., 2017). The reaction was monitored by TLC (cyclohexane /acetone 8/2). After sampling, the reaction was stopped by acidifying the mixture with concentrated $\mathrm{HCl}(37 \%)$ to neutralize the remaining alkali, and was allowed to stand for phase separation (for $24 \mathrm{~h}$ ). The organic layer was left for phase separation 3 times and the collected fractions were dried on anhydrous $\mathrm{CaCl}_{2}$ to give methyl ricinoleate $(24.5 \mathrm{~g}, 98 \%) ; \mathrm{R}_{\mathrm{F}}: 0.65$ (cyclohexane /acetone $8 / 2)$. UV ( $\lambda \max ) \mathrm{nm}$ : 204. IR $\left(\mathrm{CCl}_{4}\right), v \mathrm{~cm}^{-1}: 3430.74(\mathrm{OH}) ; 3008(\mathrm{C}=\mathrm{C}) ;(2928.38$ and 2856) (alkyl groups); 3008(CH unsaturated); 1737.55(C = O). ${ }^{1} \mathrm{H}$ NMR (400 MHZ, DMSO $\left.\mathrm{d}_{6}\right) \delta(\mathrm{ppm}):(5.42 ; 5.38 ; 5.27)\left(\mathrm{m}, 1 \mathrm{H}, \mathrm{H}_{10}\right.$ and $\left.\mathrm{H}_{9}\right)$; $4.38\left(\mathrm{t}, 3 \mathrm{H}, \mathrm{O}-\mathrm{CH}_{3}\right) ; 4.01\left(\mathrm{t}, 3 \mathrm{H}, \mathrm{O}-\mathrm{CH}_{3}\right) ; 3.40(\mathrm{~s}, 1 \mathrm{H}$, $\mathrm{OH}) ; 2.23-1.14(\mathrm{~m}, 32 \mathrm{H}, \mathrm{CH}$ paraffinic); 0.84; $0.82\left(\mathrm{t}, 3 \mathrm{H}, \mathrm{CH}_{3}\right.$ terminal). ${ }^{13} \mathrm{C}$ NMR (400 MHZ, 
DMSO $\left.\mathrm{d}_{6}\right) \delta$ ppm: $175.0 ; 172.9 ; 130.8 ; 129.9 ; 127.8$; $70.4 ; 60.0 ; 35.6 ; 34.2 ; 31.2 ; 29.6 ; 29.5 ; 28.6 ; 28.6$; $27.5 ; 26.8 ; 22.9 ; 14.2$. MS: Molecular formula $\mathrm{C}_{18} \mathrm{H}_{36} \mathrm{O}_{3}$ : 311, m/z: $311(\mathrm{M}+, 100 \%)$.

\subsubsection{Ricinoleic acid hydrazide}

Methyl ricinoleate $(2),(2.11 \mathrm{~g} ; 0.01 \mathrm{~mol})$, ethanol $(50 \mathrm{~mL})$ and hydrazine hydrate $64 \%(12 \mathrm{~mL})$ were refluxed for $10 \mathrm{~h}$. Ethanol and hydrazine were evaporated under reduced pressure, white solid was produced, recrystallized from acetone/ cyclohexane to give ricinoleic hydrazide (3), $2.2 \mathrm{~g}$, 90\%). M.p. $\left(80-85{ }^{\circ} \mathrm{C}\right)$; UV ( $\left.\lambda \max \right) \mathrm{nm}: 205 ; 262$. IR $(\mathrm{KBr}), v \mathrm{~cm}^{-1}$ : 3323. $71\left(\mathrm{OH}, \mathrm{NH}, \mathrm{NH}_{2}\right) ; 3008$ $(\mathrm{HC}=\mathrm{C}) ; 2849.31$ and 2918.73 (alkyl groups); 1636. $3(\mathrm{~N}-\mathrm{C}=\mathrm{O}) .{ }^{1} \mathrm{H}$ NMR (400 MHZ, DMSO $\left.\mathrm{d}_{6}\right) \delta(\mathrm{ppm}): 8.88(\mathrm{~s}, 1 \mathrm{H}, \mathrm{NH}) ; 5.39\left(\mathrm{~m}, 1 \mathrm{H}, \mathrm{H}_{10}\right) ; 5.37$ $\left(\mathrm{m}, 1 \mathrm{H}, \mathrm{H}_{9}\right) ; 3.34(\mathrm{~s}, 1 \mathrm{H}, \mathrm{OH}) ; 4.37\left(\mathrm{~d}, 2 \mathrm{H}, \mathrm{NH}_{2}\right)$; 2.08-1.16 (m, 32H, CH paraffinic); $0.84\left(\mathrm{t}, 3 \mathrm{H}, \mathrm{CH}_{3}\right.$ terminal). ${ }^{13} \mathrm{C}$ NMR (400MHZ, DMSO $\left.\mathrm{d}_{6}\right) \delta$ ppm: $172.3 ; 128.4 ; 69.7 ; 37.9 ; 37.6 ; 34.2 ; 31.2 ; 29.6 ; 29.4$; $28.6 ; 25.6 ; 22.9 ; 21.9 ; 14.28$. MS: Molecular formula $\mathrm{C}_{18} \mathrm{H}_{36} \mathrm{~N}_{2} \mathrm{O}: 312, \mathrm{~m} / \mathrm{z}$ : $312(\mathrm{M}+, 100 \%)$.

\subsubsection{5-Ricinoleyl-1,3,4-oxadiazole-2-thione-thiol}

Ricinoleic acid hydrazide (3), (1g; 0.0032 mol) in ethanol $(80 \mathrm{~mL})$ was added to $\mathrm{CS}_{2}(30 \mathrm{~mL})$ followed by $(1.2 \mathrm{~g}) \mathrm{KOH}$, and the mixture was refluxed for $16 \mathrm{~h}$ until the release of $\mathrm{H}_{2} \mathrm{~S}$ had ceased. The mixture was then cooled and acidified with dilute $\mathrm{HCl}$. The crude compound was recrystallized from chloroform to give 5-Ricinoleyl-1,3,4-oxadiazole-2thione-thiol (4), (1.36 g, 70\%), $\mathrm{R}_{\mathrm{f}:} 0.64$ (cyclohexane /acetone $7 / 3)$; m.p. (117-120), UV ( $\lambda \max ) \mathrm{nm}$ : 205; 252. IR (KBr), $v \mathrm{~cm}^{-1}$ : 3418. $21(\mathrm{OH}) ; 3222.47$ (NH); (2957, 2868) (alkyl groups); 3046 (CH unsaturated); $2800(\mathrm{~S}-\mathrm{H}) ; 1594(\mathrm{C}=\mathrm{N}) ; 1423(\mathrm{C}=\mathrm{S}) ; 1109$ (COC). ${ }^{1}$ H NMR (400 MHZ, DMSO d 6 ) $\sigma(\mathrm{ppm})$ : 14.38(s, 1H, SH); $5.75\left(\mathrm{~m}, 1 \mathrm{H}, \mathrm{H}_{10}\right) ; 5.85(\mathrm{~m}, 1 \mathrm{H}$, $\left.\mathrm{H}_{9}\right) ; 3.42(\mathrm{~s}, 1 \mathrm{H}, \mathrm{OH}) ; 3.33(\mathrm{~s}, 1 \mathrm{H}, \mathrm{OH}) ; 2.69-1.21(\mathrm{~m}$, $32 \mathrm{H}, \mathrm{CH}$ paraffinic); $0.84\left(\mathrm{t}, 3 \mathrm{H}, \mathrm{CH}_{3}\right.$ terminal). ${ }^{13} \mathrm{C}$ NMR (400 MHZ, DMSO d $\mathrm{d}_{6}$ $\delta$ ppm: 180.7; 174.3; $164.7 ; 144.28 ; 130.21 ; 70.27 ; 39.9 ; 37.6 ; 31.1 ; 29.3$; $26.7 ; 24.7 ; 24.4 ; 24.0 ; 22.5 ; 14.5$. MS: Molecular formula $\mathrm{C}_{19} \mathrm{H}_{34} \mathrm{~N}_{2} \mathrm{O}_{2} \mathrm{~S}: 354, \mathrm{~m} / \mathrm{z} 279\left(\mathrm{C}_{19} \mathrm{H}_{34} \mathrm{~N}\right) ; \mathrm{m} / \mathrm{z} 297$ $\left(\mathrm{C}_{19} \mathrm{ON}\right), \mathrm{m} / \mathrm{z} 75$ (CNOS) and $\mathrm{m} / \mathrm{z} 59$ (CNS).

\subsubsection{5-Ricinoleyl-1,3,4-thiadiazole-2-thione}

The ricinoleic acid hydrazide (3), (1 g, 0.0032 mole) was mixed with $\mathrm{KOH}(0.5 \mathrm{~g})$ dissolved in absolute ethanol. A solution of $\mathrm{CS}_{2}(2.5 \mathrm{~g})$ was added to the mixture with $15 \mathrm{~mL}$ of ethanol. The mixture was stirred for $1 \mathrm{~h}$ at room temperature and then refluxed for 24 hours. The final product was acidified with hydrochloric acid. The resulting solid residue was filtered and recrystallized from ethanol. The product was obtained in the form of yellowish crystals (5), (1.45g, 75\%); $\mathrm{R}_{\mathrm{F}:} 0.35$ (cyclohexane /acetone 6/4); m.p. $97^{\circ} \mathrm{C}$. UV $(\lambda \max ) \mathrm{nm}: 205 ; 285$. IR $\left(\mathrm{CCl}_{4}\right), v \mathrm{~cm}^{-1}$ : 3308.29(OH,NH); 2980.45(C = C); $(2921.63,2849.31)$ (alkyl groups); 1589.06(C = N); 1462.74(C = S). 1H NMR (400 MHZ, DMSO d6) $\delta$ (ppm): 5.42 (s, 1H, $\mathrm{NH}) ; 5.33\left(\mathrm{~m}, 1 \mathrm{H}, \mathrm{H}_{10}\right) ; 4.75\left(\mathrm{~m}, 1 \mathrm{H}, \mathrm{H}_{9}\right) ; 3.33(\mathrm{~s}, 1 \mathrm{H}$, $\mathrm{OH}) ; 3.32(\mathrm{~s}, 1 \mathrm{H}, \mathrm{OH}) ; 2.24-1.16(\mathrm{~m}, 32 \mathrm{H}, \mathrm{CH}$ paraffinic); 0.84 (t, 3H, $\mathrm{CH}_{3}$ terminal). 13C NMR (400 MHZ, DMSO d6) $\delta$ ppm: 174.9; 173.3; 130.8; 128.9; 70.0; 64.4; 60.3; 37.9; 34.3; 31.9; 29.5; 25.7; 24.9; 22.5; 14.5. MS: Molecular formula $\mathrm{C}_{19} \mathrm{H}_{34} \mathrm{~N}_{2} \mathrm{OS}_{2}: 364 \mathrm{~m} / \mathrm{z}$ : $364(\mathrm{M}+, 100 \%)$.

\subsubsection{5-Ricinoleyl-4-amino-1, 2, 4-triazole-3-thiol}

Ricinoleic acid hydrazide (3), (1g; 0.0032 mol) and $\mathrm{KOH}(1.5 \mathrm{~g})$ in absolute ethanol $(10 \mathrm{~mL})$ were mixed together until the solution became clear. $\mathrm{CS}_{2}$ $(25 \mathrm{~mL})$ was added. The solution was stirred for $10 \mathrm{~h}$ at room temperature, and then diethyl ether (20 $\mathrm{mL})$ was added to form a precipitate ricinoylpotassium thiocarbazinic acid (6). The intermediary product was mixed with $\left(\mathrm{NH}_{2} \mathrm{NH}_{2}-\mathrm{H}_{2} \mathrm{O}\right)(4 \mathrm{~mL})$. The solution was refluxed for $15 \mathrm{~h}$ until the color of the solution became clear green. After cooling to room temperature, ice water $(10 \mathrm{~mL})$ was added to the reaction mixture, which was then neutralized with $3 \mathrm{~N} \mathrm{HCl}$ to form a precipitate. The precipitate was isolated by filtration and purified by recrystallization from ethanol/water to afford the desired product in the form of yellow crystal: 5-Ricinoleyl4-amino-1, 2, 4-triazole-3-thiol (7), 1.2g, 65\%); $\mathrm{R}_{\mathrm{f:}} 0.61$ (cyclohexane /acetone: 6/4); $\mathrm{Mp}_{\mathrm{i}}\left(132^{\circ} \mathrm{C}\right)$ $\mathrm{UV}(\lambda \max ) \mathrm{nm}: 205 ; 240$. IR $(\mathrm{KBr}), v \mathrm{~cm}^{-1}: 3417.24$ $(\mathrm{OH}) ; 3177\left(\mathrm{NH}_{2}\right) ; 2953,2868$ (alkyl groups); 2700 (SH); $1617(\mathrm{C}=\mathrm{N}) .{ }^{1} \mathrm{H}$ NMR (400 MHZ, DMSO $\left.\mathrm{d}_{6}\right) \sigma(\mathrm{ppm}): 11.97$ (s, 1H, SH); $4.22\left(\mathrm{~d}, 2 \mathrm{H}, \mathrm{NH}_{2}\right)$; $4.01\left(\mathrm{~d}, 2 \mathrm{H}, \mathrm{NH}_{2}\right) ; 5.75\left(\mathrm{~m}, 1 \mathrm{H}, \mathrm{H}_{10}\right) ; 5.39(\mathrm{~m}$, $\left.1 \mathrm{H}, \mathrm{H}_{9}\right) ; 3.34(\mathrm{~s}, 1 \mathrm{H}, \mathrm{OH}) ; 2.69-1.23(\mathrm{~m}, 32 \mathrm{H}, \mathrm{CH}$ paraffinic); 0.85 (t, 3H, $\mathrm{CH}_{3}$ terminal). ${ }^{13} \mathrm{C} \mathrm{NMR}$ (400 MHZ, DMSO d 6 ) $\delta$ ppm: 181.0; 174.3; 164,7; 128,$2 ; 123,2 ; 70.0 ; 69.9 ; 60.3 ; 37.7 ; 31.9 ; 25.7 ; 22.5$; 14.5. MS: Molecular formula $\mathrm{C}_{19} \mathrm{H}_{36} \mathrm{~N}_{4} \mathrm{OS}$ : 368 ; the pseudo-molecular peak $[\mathrm{M}+\mathrm{H}]+$ with $\mathrm{m} / \mathrm{z} 367$.

\subsubsection{N-Thiosemicarbazide ricinoleic}

Ricinoleic acid hydrazide (3), 1g; 0.0032 mol) was dissolved in ethanol $(20 \mathrm{~mL})$ with stirring. Ammonium thiocyanate $(0.58 \mathrm{~g})$ and $\mathrm{HCl}(30 \%)$ were added, and the reaction mixture was refluxed for $6 \mathrm{~h}$. Excess solvent was evaporated to almost dryness and recrystallized from methanol/petroleum ether to give $\mathrm{N}$-Thiosemicarbazide ricinoleic (8), $0.97 \mathrm{~g}, 65 \%$ ) ; $\mathrm{R}_{\mathrm{f}}: 0,45$ (cyclohexane /acetone: $7 / 3)$; $\mathrm{Mp}\left(97{ }^{\circ} \mathrm{C}\right)$; UV $(\lambda \max ) \mathrm{nm}: 210 ; 265$. IR $(\mathrm{KBr}) \vee \mathrm{cm}^{-1}: 3373.85(\mathrm{OH}) ;(3271.64,3172.33$, 3106.76) ( $\mathrm{NH}$ and $\left.\mathrm{NH}_{2}\right) ;(2851.24$ and 2919.70) 
(alkyl groups); $1699(\mathrm{C}=\mathrm{O}) ; 1621(\mathrm{C}=\mathrm{O}-\mathrm{N}) ; 1492$ $(\mathrm{C}=\mathrm{S}) .{ }^{1} \mathrm{H}$ NMR (400 MHZ, DMSO d 6 ) $\sigma(\mathrm{ppm})$ : 8.87 (s, 1H, NH); $8.44(\mathrm{~s}, 1 \mathrm{H}, \mathrm{NH}) ; 4.32(\mathrm{~d}, 2 \mathrm{H}$, $\left.\mathrm{NH}_{2}\right) ; 5.36\left(\mathrm{~m}, 1 \mathrm{H}, \mathrm{H}_{10}\right.$ and $\left.\mathrm{H}_{9}\right) ; 3.33(\mathrm{~s}, 1 \mathrm{H}, \mathrm{OH})$; 2.68-1.21 (m, 32 H, CH paraffinic); $0.84\left(\mathrm{t}, 3 \mathrm{H}, \mathrm{CH}_{3}\right.$ terminal). ${ }^{13} \mathrm{C}$ NMR (400 MHZ, DMSO d 6 ) $\delta$ ppm: $183.0 ; 178.4 ; 166.9 ; 164.7 ; 131.7 ; 127.5 ; 70.4 ; 69.9$; $37.6 ; 29.3 ; 29.3 ; 28.6 ; 25.5 ; 25.4 ; 25.2 ; 14.5$. MS: Molecular formula $\mathrm{C}_{19} \mathrm{H}_{37} \mathrm{~N}_{3} \mathrm{O}_{2} \mathrm{~S}: 371, \mathrm{~m} / \mathrm{z}: 371$ $(\mathrm{M}+, 100 \%)$.

\subsubsection{5-Ricinoleyl-4H-1, 2, 4-triazole-3-thiol}

N-Thiosemicarbazide ricinoleic (8), (1.0 g; 0.0024 $\mathrm{mol})$ in ethanol $(15 \mathrm{~mL})$ was added to an alcoholic solution of $10 \% \mathrm{NaOH}(20 \mathrm{~mL})$, and the reaction mixture was refluxed for $12 \mathrm{~h}$. The mixture was cooled and acidified with dilute $\mathrm{HCl}$ to $\mathrm{pH}(5-6)$. The crude compound was recrystallized from ethanol to give white needle-like crystals: 5-Ricinoleyl4H-1,2,4-triazole-3-thiol (9), (0.75 g, 75\%) ; m.p. $\left(95{ }^{\circ} \mathrm{C}\right) ; \mathrm{R}_{\mathrm{f}}: 0.46$ (cyclohexane /acetone: 6/4) ; UV $(\lambda \max ) \mathrm{nm}: 210$. IR $(\mathrm{KBr}) v \mathrm{~cm}^{-1}: 3433(\mathrm{OH}, \mathrm{NH})$; $3100(\mathrm{C}=\mathrm{C}) ; 2953$ and 2868 (alkyl groups); 2722.05 $(\mathrm{SH}) ; 1636.3(\mathrm{C}=\mathrm{N}) .{ }^{1} \mathrm{H}$ NMR (400 MHZ, DMSO $\left.\mathrm{d}_{6}\right) \sigma(\mathrm{ppm}): 12.34(\mathrm{~s}, 1 \mathrm{H}, \mathrm{SH}) ; 4.57(\mathrm{~s}, 1 \mathrm{H}, \mathrm{NH})$; 5.75; $5.90\left(\mathrm{~m}, 1 \mathrm{H}, \mathrm{H}_{10}\right.$ and $\left.\mathrm{H}_{9}\right) ; 3.72(\mathrm{~s}, 1 \mathrm{H}, \mathrm{OH})$; 2.85-1.18 (m, 32H, CH paraffinic); $0.96(\mathrm{t}, 3 \mathrm{H}$, $\mathrm{CH}_{3}$ terminal). ${ }^{13} \mathrm{C}$ NMR (400 MHZ, DMSO d 6 ) $\delta$ ppm: $175.3 ; 174.7 ; 130.2 ; 125.2 ; 69.7 ; 39.9 ; 31.8$; $29.9 ; 25.2 ; 24.9 ; 22.9 ; 14.5$. MS: Molecular formula $\mathrm{C}_{19} \mathrm{H}_{35} \mathrm{~N}_{3} \mathrm{OS}:$ 353, The pseudo-molecular peak $[\mathrm{M}+\mathrm{H}]+$ with $\mathrm{m} / \mathrm{z} 354$.

\subsubsection{5-Ricinoleyl-2-amino-1,3,4-oxadiazole}

N-Thiosemicarbazide ricinoleic (8); (1.0 g, 0.0026 mol) was dissolved in an alcoholic solution of $\mathrm{NaOH}$ $(5 \mathrm{~N})$ with the aid of stirring. The mixture was refluxed at $80{ }^{\circ} \mathrm{C}$, during which an aqueous iodine solution $\left(\mathrm{KI} / \mathrm{I}_{2}\right.$ ) was added gradually until the iodine color (pink-purple) persisted. Reflux was continued for $15 \mathrm{~h}$. Once the solution had cooled, it was filtered and then treated with a dilute sodium thiosulfate solution and finally washed with distilled water to give a strawyellow solid which was recrystallized from ethanol to give 5-Ricinoleyl-2-amino-1,3,4-oxadiazole (10), $(0.78 \mathrm{~g}, 78 \%)$; m.p $\left(128^{\circ} \mathrm{C}\right) ; \mathrm{R}_{\mathrm{f}}: 0.56$ (cyclohexane / acetone : 6/4) ; UV ( $\lambda \max ) \mathrm{nm}: 210 ; 275$. IR (KBr), $v \mathrm{~cm}^{-1}$ : $3389\left(\mathrm{OH}, \mathrm{NH}_{2}\right) ; 2921.63$ and 2850.27 (alkyl groups); $165.45(\mathrm{O}-\mathrm{C}=\mathrm{N}) ; 1119(=\mathrm{C}-\mathrm{O}-\mathrm{C}=) .{ }^{1} \mathrm{H}$ NMR (400 MHZ, DMSO d $\mathrm{d}_{6} \delta(\mathrm{ppm}): 5.54(\mathrm{~d}, 2 \mathrm{H}$, $\left.\mathrm{NH}_{2}\right) ; 5.30\left(\mathrm{~m}, 1 \mathrm{H}, \mathrm{H}_{10}\right) ; 5.23\left(\mathrm{~m}, 1 \mathrm{H}, \mathrm{H}_{9}\right) ; 3.32(\mathrm{~s}, 1 \mathrm{H}$, $\mathrm{OH}) ; 2.51-1.23$ (m, 32H, CH paraffinic); $0.85(\mathrm{t}, 3 \mathrm{H}$, $\mathrm{CH}_{3}$ terminal). ${ }^{13} \mathrm{C}$ NMR (400 MHZ, DMSO $\left.\mathrm{d}_{6}\right) \delta$ ppm: $175.6 ; 174.9 ; 131.5 ; 125.5 ; 70.0 ; 37.3 ; 34.1 ; 31.9$; $31.2 ; 29.3 ; 28.6 ; 25.6 ; 25.2 ; 22.6 ; 14.5$. MS: Molecular formula $\mathrm{C}_{19} \mathrm{H}_{35} \mathrm{~N}_{3} \mathrm{O}_{2}: 337, \mathrm{~m} / \mathrm{z} 253\left(\mathrm{C}_{18} \mathrm{H}_{33} \mathrm{O}\right) ; \mathrm{m} / \mathrm{z} 279$ $\left(\mathrm{C}_{19} \mathrm{H}_{33} \mathrm{CN}\right) ; \mathrm{m} / \mathrm{z} 84\left(\mathrm{C}_{2} \mathrm{HON}_{3}\right)$ and $\mathrm{m} / \mathrm{z} 58\left(\mathrm{CON}_{2} \mathrm{H}_{2}\right)$.

\subsubsection{5-Ricinoleyl-2-amino-1,3,4-thiadiazole 11.}

N-Thiosemicarbazide ricinoleic (8, 1.0 g; 0.0024 mol) was added gradually under stirring to the cooled concentrated $\mathrm{H}_{2} \mathrm{SO}_{4}(30 \mathrm{~mL})$ for $1 \mathrm{~h}$. the reaction mixture was refluxed for $10 \mathrm{~h}$ in an oil bath. The precipitated solid was filtered, washed with water, dried and recrystallized with ethanol to give brown crystals (11, $0.40 \mathrm{~g}, 40 \%)$; m.p. $\left(110^{\circ} \mathrm{C}\right)$; $\mathrm{R}_{\mathrm{f}}: 0.43$ (cyclohexane /acetone: $6 / 4) \mathrm{UV}(\lambda \max ) \mathrm{nm}: 210 ; 240$. IR $(\mathrm{KBr}) v \mathrm{~cm}^{-1}$ : $3444.24\left(\mathrm{OH}, \mathrm{NH}_{2}\right) ; 2955.38(\mathrm{C}=\mathrm{C}-\mathrm{CH}) ;(2920.66$ and 2849.31) (alkyl groups); $1657.52(\mathrm{~S}-\mathrm{C}=\mathrm{N}) .{ }^{1} \mathrm{H}$ NMR (400 MHZ, DMSO d $\left.\mathrm{d}_{6}\right) \sigma(\mathrm{ppm}): 4.57$ (d, 2H, $\left.\mathrm{NH}_{2}\right) ; 5.38\left(\mathrm{~m}, 1 \mathrm{H}, \mathrm{H}_{10}\right) ; 5.57\left(\mathrm{~m}, 1 \mathrm{H}, \mathrm{H}_{9}\right) ; 3.37(\mathrm{~s}, 1 \mathrm{H}$, $\mathrm{OH}) ; 2.58-1.16(\mathrm{~m}, 32 \mathrm{H}, \mathrm{CH}$ paraffinic); $0.82(\mathrm{t}, 3 \mathrm{H}$, $\mathrm{CH}_{3}$ terminal). ${ }^{13} \mathrm{C}$ NMR (400 MHZ, DMSO $\left.\mathrm{d}_{6}\right) \delta$ ppm: 174.3; 173.3; 134.6; 128.5; 69.7; 61.0; 60.03; 37.0; 31.9; 29.4; 25.7; 25.2; 24.9; 22.9; 14.2. MS: Molecular formula $\mathrm{C}_{19} \mathrm{H}_{35} \mathrm{~N}_{3} \mathrm{OS}: 353, \mathrm{~m} / \mathrm{z} 279\left(\mathrm{C}_{19} \mathrm{H}_{33} \mathrm{~N}\right) ; \mathrm{m} / \mathrm{z}$ $227\left(\mathrm{C}_{13} \mathrm{H}_{21} \mathrm{NOS}\right) ; \mathrm{m} / \mathrm{z} 74\left(\mathrm{CHN}_{2} \mathrm{~S}\right) ; \mathrm{m} / \mathrm{z} 59\left(\mathrm{CH}_{2} \mathrm{~N}_{2}\right)$.

\subsection{Biology}

\subsubsection{Antimicrobial activities}

All the synthesized compounds were tested for their in vitro antimicrobial activity against the Gram positive bacteria Staphylococcus aureus (ATCC25923), Enterococcus faecalis (ATCC-29212), Bacillus cereus (ATCC 21332), the Gram-negative bacteria Pseudomonas aeruginosa (ATCC-27853), Escherichia coli (ATCC-25922), Klebsiella planticola (ATCC33531), Salmonella, Proteus vulgarus ( ATCC 29905), in the nutrient agar media and fungi Candida albicans (ATCC 10231), Aspergillus niger (ATCC 16404), Trichosporon $S p$, Fusarium, Penicillium $S p$ and Altenaria in Sabouraud dextrose medium using the serial plate dilution method. The data for the minimum inhibitory concentrations (MIC) (10, 5, $2.5,1.25,0.625) \mu \mathrm{g} / \mathrm{mL}$ were determined for those compounds which demonstrated activity in the preliminary paper disk tests. The standard antibiotics

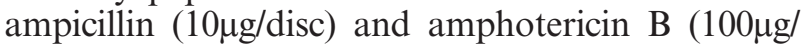
disc) were used as reference drugs for the antibacterial and antifungal activities, respectively.

\subsubsection{Antioxidant activity (DPPH radical scavenging assay)}

The DPPH solution was prepared in advance by dissolving $4 \mathrm{mg}$ of DPPH in $100 \mathrm{~mL}$ of absolute methanol. $0.1 \mathrm{~mL}$ of each sample at different concentrations $(65.5 ; 125 ; 250 ; 500 ; 1000) \mu \mathrm{g} / \mathrm{mL}$ were added to $3.9 \mathrm{~mL}$ of DPPH. Reference antioxidant solutions (ascorbic acid) were also prepared under the same conditions to serve as a positive control. The negative control consisted only of DPPH and methanol. The mixture was left in the dark for $30 \mathrm{~min}$ until discoloration. The 
presence of the DPPH radicals gave a dark purple color to the solution and which was absorbed rapidly at $517 \mathrm{~nm}$ when reduced. The color became pale yellow. During the reaction, the layer of this radical became saturated on contact with an antioxidant, which explained the disappearance of its coloring. This discoloration highlighted the trapping power of the free radical by the tested product. The percentage of the anti-free radical activity was estimated according to the equation below (Vijayalaxmi et al., 2015):

$\mathrm{PI} \%=($ Abs control - Abs product $/$ Abs control $) * 100$

PI: Percentage inhibition Abs control: Absorbance at the $517 \mathrm{~nm}$ wavelength of the negative control (DPPH + methanol).

\subsection{3. $\alpha$-Amylase inhibition activity}

The $\alpha$-amylase inhibitory activity of the synthetic compounds was determined using the chromogenic DNSA method with a few modifications (Adegboye et al., 2018). $300 \mu$ of $0.02 \mathrm{M}$ sodium phosphate buffer ( $\mathrm{pH}$ 6.9) containing $\alpha$-amylase solution $(0.5 \mathrm{mg} /$ $\mathrm{mL}$ ) and $300 \mu \mathrm{l}$ of sample at different concentrations $(62.5 ; 125 ; 250 ; 500 ; 1000) \mu \mathrm{g} / \mathrm{mL}$ were incubated at $37^{\circ} \mathrm{C}$ for $30 \mathrm{~min}$. Afterwards, $300 \mu \mathrm{l}$ of a $1 \%$ starch solution in $0.02 \mathrm{M}$ sodium phosphate buffer were added to each tube at timed intervals. The reaction mixtures were then incubated at $37^{\circ} \mathrm{C}$ for $15 \mathrm{~min}$. The reaction was stopped with $0.5 \mathrm{~mL}$ of dinitrosalicylic acid (DNSA) color reagent. The reaction mixture was then diluted after adding $5 \mathrm{~mL}$ of distilled water, and absorbance was measured at $540 \mathrm{~nm}$. The $\alpha$-amylase inhibitory activity was calculated as follows:

$$
\text { Inhibition } \%=1-\left(\mathrm{A}_{\text {samp }} / \mathrm{A}_{\text {cont })} 100 \%\right) \text {. }
$$

Where $\mathrm{A}_{\text {samp }}$ and $\mathrm{A}_{\text {cont }}$ were defined as absorbance of the sample and the control, respectively.

\section{RESULTS AND DISCUSSION}

\subsection{Synthesis}

The ricinoleiate triglyceride (1) was catalytically transesterified with methanol to give methyl ricinoleiate (2) in quantitative yield (Kumar et al., 2017) and converted to hydrazide (3) (Joshi et al., 2017), as summarized in Figure 1. Hydrazide (3) was subjected to synthetic modifications to reveal recinoleic diazoles and triazole derivatives: 1, 3,4-oxadiazole-5-thione (4), 1,3,4-thiadiazole-5-thione (5), 4-N-amino1,2,4-triazole-5-thiol (7), 1,2,4-triazole-5-thiol (9), 5-amino- 1,3,4-oxadiazole (10), 5-amino1,3,4-thiadiazole (11) and as summarized in

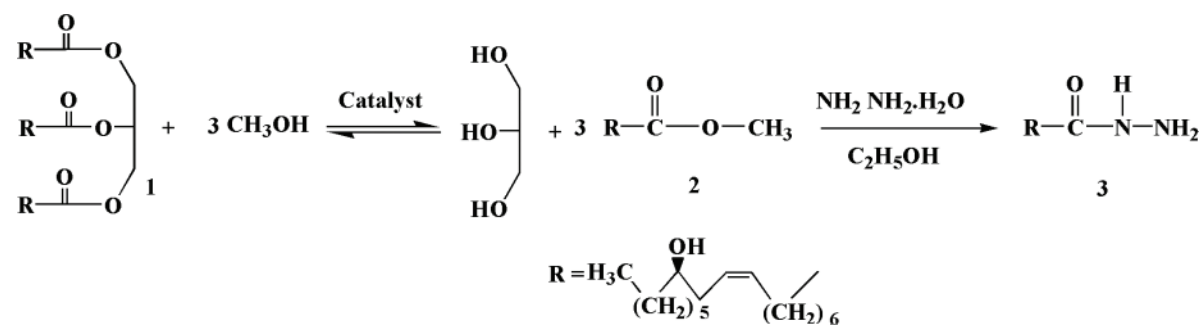

FIgURE 1. Conversion of ricinoleic triglyceride (1) to ricinoleic hydrazide (3).

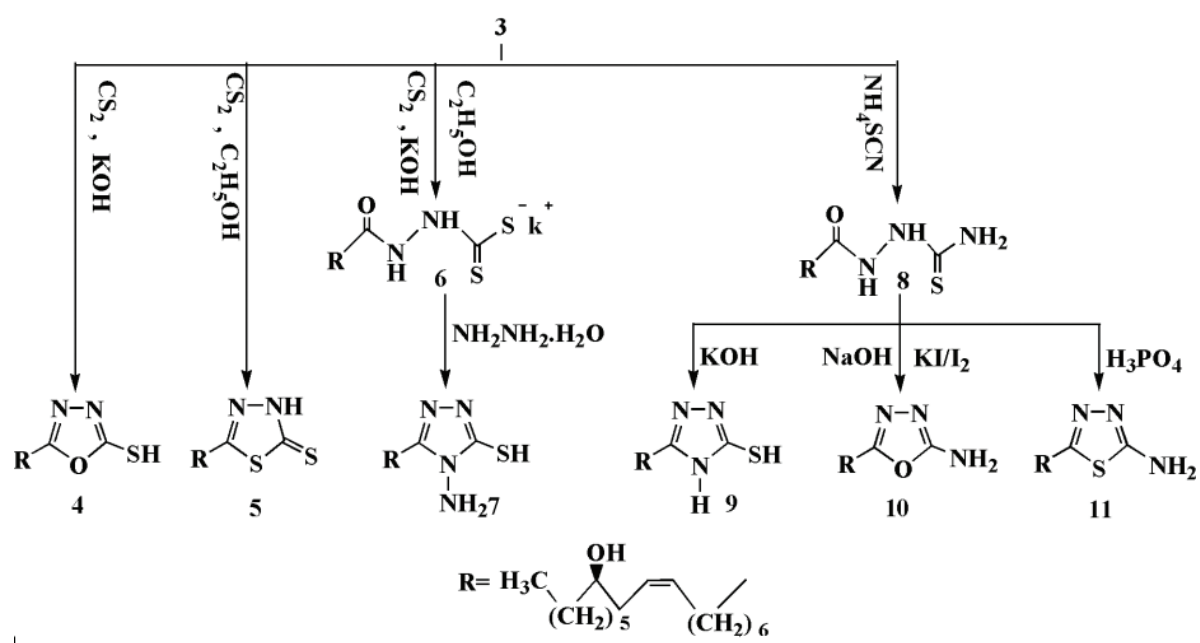

Figure 2. Synthetic pathways to diazole and triazole derivatives (4), (5), (7), (9), (10) and (11) of ricinoleic 

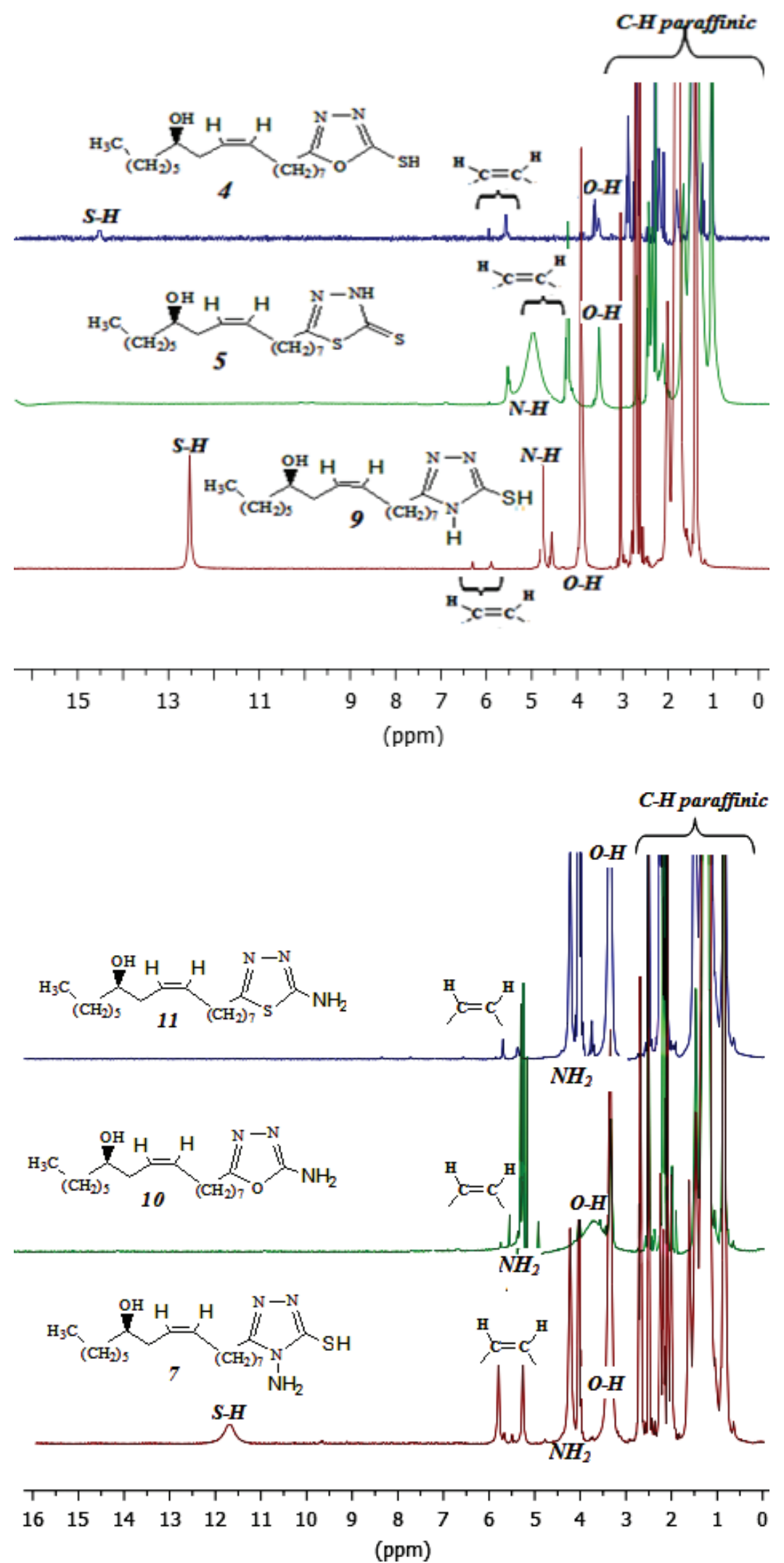

FiguRE 3. Characteristic signals in $\mathrm{H}^{1} \mathrm{NMR}$ of heterocyclic derivatives: 5-Ricinoleyl-1,3,4-oxadiazole-2-thione-thiol (4) 5-Ricinoleyl-1,3,4-thiadiazole-2-thione (5), 5-Ricinoleyl-4-amino-1, 2, 4-triazole-3-thiol (7), 5-Ricinoleyl-4H-1,2,4-triazole-3-thiol (9), 5-Ricinoleyl-2-amino-1,3,4-oxadiazole (10), 5-Ricinoleyl-2-amino-1,3,4-thiadiazole (11). 
figure 2. The first set of heterocyle derivatives 4, 5 and 7 were achieved by refluxing hydrazide 3 with $\mathrm{CS}_{2}$ and aqueous $\mathrm{KOH}$ to give 2-ricinoleyl-1,3,4-oxadiazole-5-thiol (4) (Taieb Brahimi et al., 2017). While using the excess $\mathrm{CS}_{2}$ it yielded 2-ricinoleyl-1,3,4-thiadiazole-5-thione (5) (Gad El-Karim et al., 2013). However, heating hydrazide (3) with $\mathrm{CS}_{2}$ in alcoholic $\mathrm{KOH}$ resulted in the crude ricinoleic potassium thiocarbazinic acid (6), which without separation and further analysis was refluxed with hydrazine hydrate to give 5-ricinoleyl-4- amino-1,2,4-triazole-3thiol (7)

The second set of heterocycles (9-1)1 was prepared from $\mathrm{N}$-thiosemicarbazide ricinoleic (8), which had already been prepared by treating hydrazide (3) with ammonium thiocyanide. 5-Ricinoleyl4H-1,2,4-triazole-3-thiol (9) was obtained by the cyclization of 8 with $\mathrm{KOH}$ (Belkhadem et al., 2017); while 2-amino oxadiazole (10) was isolated

TABle 1. Antibacterial activity of castor oil (1) and its synthesized derivatives (2-11).

\begin{tabular}{|c|c|c|c|c|c|c|c|c|}
\hline \multirow[b]{3}{*}{ Compound } & \multicolumn{4}{|c|}{ Gram-positive bacteria } & \multicolumn{4}{|c|}{ Gram-negative bacteria } \\
\hline & S.a. & E.f. & B.c. & P.a. & E.c. & K.P. & Sal. & P.v. \\
\hline & \multicolumn{8}{|c|}{ Zone of inhibition in mm and MIC (minimum inhibitory concentration) in $\mu \mathrm{g} / \mathrm{mL}$} \\
\hline 1 & - & - & $7(100)$ & $7(25)$ & $7(25)$ & $8(50)$ & $10(6.5)$ & $10(25)$ \\
\hline 2 & - & - & $7(50)$ & $7(25)$ & $8(25)$ & $7(50)$ & $12(25)$ & $10(25)$ \\
\hline 3 & - & - & - & - & $10(25)$ & $10(25)$ & $15(25)$ & - \\
\hline 4 & $14(6.25)$ & $7(50)$ & - & $7(100)$ & $10(12.5)$ & $10(25)$ & $15(12.5)$ & $8(25)$ \\
\hline 5 & $10(6.25)$ & $12(25)$ & - & - & $8(25)$ & $10(25)$ & $10(6.25)$ & $8(25)$ \\
\hline 7 & $7(25)$ & $9(50)$ & $7(25)$ & $7(25)$ & - & $10(25)$ & $10(25)$ & - \\
\hline 8 & $25(100)$ & $7(100)$ & $7(50)$ & $8(25)$ & $10(6.25)$ & $8(50)$ & $10(6.25)$ & $10(100)$ \\
\hline 9 & $7(25)$ & $7(50)$ & - & $7(50)$ & $7(25)$ & $10(25)$ & $7(50)$ & $8(25)$ \\
\hline 10 & $7(50)$ & $7(12.5)$ & $7(50)$ & $7(50)$ & - & $8(25)$ & $10(25)$ & - \\
\hline 11 & $8(50)$ & $8(50)$ & $7(100)$ & $7(100)$ & - & $10(25)$ & $10(25)$ & - \\
\hline Amp & 25 & 8 & 32 & 15 & 20 & 32 & 18 & 22 \\
\hline
\end{tabular}

The figures in the table show the zone of inhibition $(\mathrm{mm})$ and the corresponding MIC $(\mu \mathrm{g} / \mathrm{mL})$ values in brackets. Amp: Ampicillin $(10 \mu \mathrm{g} /$ disc $)$.

S.a. (Staphylococcus aureus), E.f. (Enterococcus faecalis), B.c. (Bacillus cereus), P.a. (Pseudomonas aeruginosa),

E.c. (Escherichia coli), K.P. (Klebsiella planticola), Sal. (Salmonella), P.v. (Proteus vulgarus).

TABLE 2. Antifungal activity of castor oil (1) and its synthesized derivatives (2-11) at $100 \mu \mathrm{g} / \mathrm{mL}$.

\begin{tabular}{|c|c|c|c|c|c|c|}
\hline \multirow[b]{3}{*}{ Compound } & \multicolumn{5}{|c|}{ Fungi } & \\
\hline & \multicolumn{3}{|c|}{ Mold } & \multicolumn{3}{|c|}{ Yeast } \\
\hline & Candida albicans & Trichosporon Sp & Aspergillus niger & Fusarium & Penicillium Sp & Altenaria \\
\hline 1 & - & - & +++ & - & - & +++ \\
\hline 2 & - & - & ++ & - & - & +++ \\
\hline 3 & ++ & ++ & - & + & +++ & - \\
\hline 4 & ++ & ++ & - & - & - & + \\
\hline 5 & ++ & ++ & - & - & - & + \\
\hline 7 & +++ & - & - & - & - & ++ \\
\hline 8 & - & +++ & - & +++ & +++ & - \\
\hline 9 & - & - & - & - & - & + \\
\hline 10 & ++ & +++ & - & +++ & - & +++ \\
\hline 11 & - & ++ & - & +++ & - & +++ \\
\hline Ref & +++ & ++ & +++ & + & +++ & +++ \\
\hline
\end{tabular}

Key to the inhibition zones activities: Highly active $=(21-30 \mathrm{~mm})+++;$ Moderately active $=(16-20 \mathrm{~mm})++;$ Slightly active $=(10-15 \mathrm{~mm})$ + ; Inactive $=(<10 \mathrm{~mm})$ -

Ref: amphotericin B (100 $\mu \mathrm{g} / \mathrm{disc}$.$) .$ 

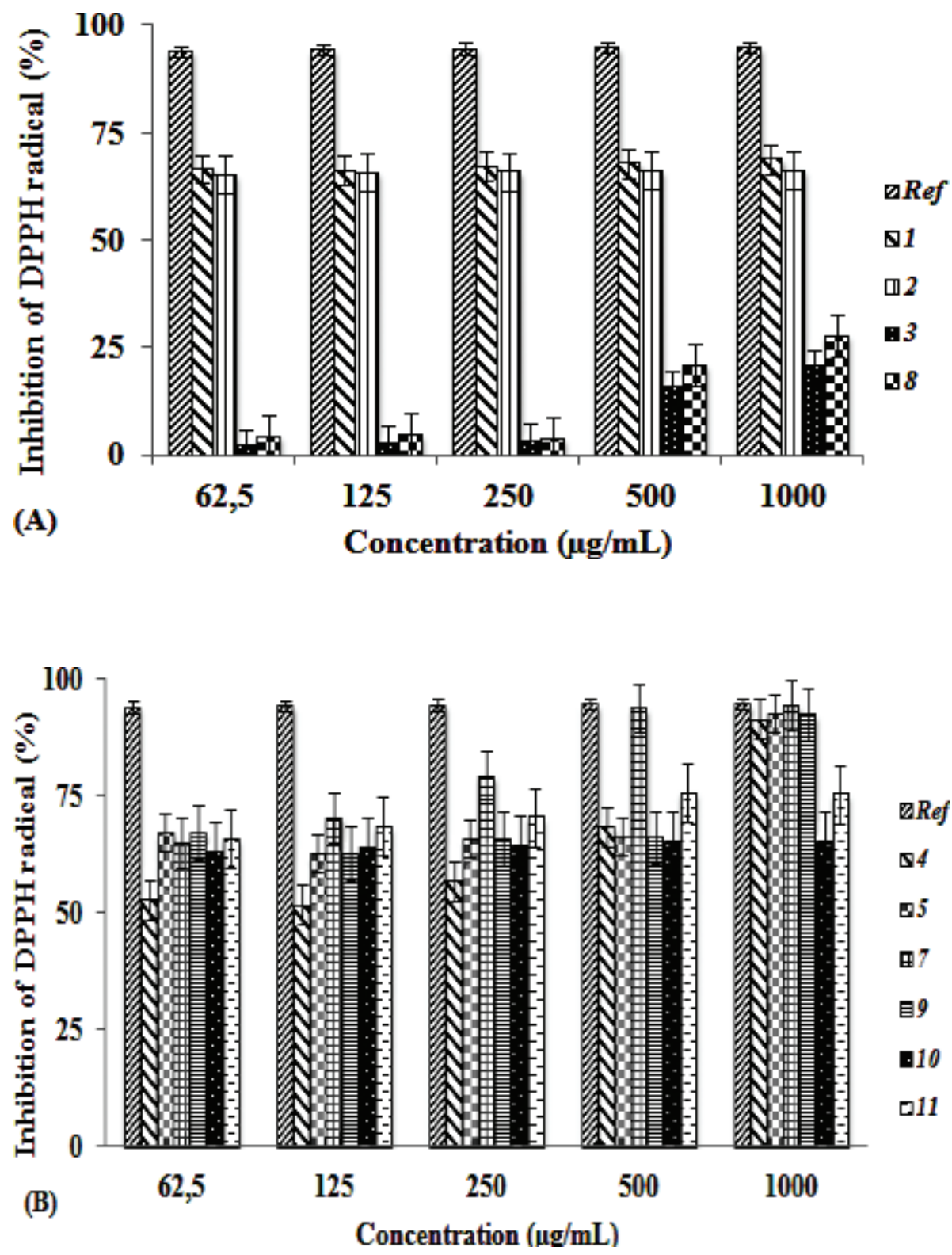

FIGURE 4. DPPH scavenging effect (\%) of castor oil and its synthesized derivatives at different concentrations of: (A) Intermediate compounds: Castor oil (1), Methyl ricinoleate (2), Ricinoleic acid hydrazide (3), N-Thiosemicarbazide ricinoleic (8) and ascorbic acid as reference. (B) Heterocyclic synthetic products: 5-Ricinoleyl-1,3,4-oxadiazole-2-thione-thiol (4), 5-Ricinoleyl1,3,4-thiadiazole-2-thione (5), 5-Ricinoleyl-4-amino-1, 2, 4-triazole-3-thiol (7), 5-Ricinoleyl-4H-1,2,4-triazole-3-thiol (9),

5-Ricinoleyl-2-amino-1,3,4-oxadiazole (10), 5-Ricinoleyl-2-amino-1,3,4-thiadiazole (11) and Ascorbic acid as reference. Each point shows the average value of three replicates \pm SD.

after treating 8 with $\mathrm{NaOH}$ in the presence of $\mathrm{I}_{2} /$ KI. 2-Amino thiadiazole (11) was collected after reacting (8) with $\mathrm{H}_{3} \mathrm{PO}_{4}$. The structural determination of all synthetic compounds 2-11 was confirmed spectroscopically by IR, UV, ${ }^{1} \mathrm{H}-\mathrm{NMR}$, ${ }^{13} \mathrm{C}-\mathrm{NMR}$ and MS (see Figure 3). All compounds 1-11 became available, and a study of their antimicrobial, antioxidant and hypoglycemic activities was carried out.

\subsection{Pharmacological screening}

\subsubsection{Antimicrobial activities}

The results for antimicrobial activities are summarized in Tables 1 and 2.

The gram-positive bacteria under consideration showed zones of inhibition inferior to those observed by the Gram-negative bacteria. In general, the first 
TABLE 3. IC $_{50}$ values for castor oil 1 and its synthesized derivatives (2-11) with references of DPPH scavenging and $\alpha$ amylase inhibitory activity.

\begin{tabular}{|c|c|c|c|}
\hline Compound & $\begin{array}{c}\text { DPPH Scavenging } \\
\text { Activity } \\
\text { (IC50 }(\mu \mathrm{g} / \mathrm{mL})\end{array}$ & $\begin{array}{l}\text { Antiradical } \\
\text { Power } \\
\text { (1/ IC50) }\end{array}$ & $\begin{array}{c}\alpha \text {-amylase inhibitory } \\
\text { activity } \\
(\mathrm{IC} 50(\mu \mathrm{g} / \mathrm{mL}))\end{array}$ \\
\hline 1 & $32,16 \pm 0.58$ & 0,031 & $130.42 \pm 2.48$ \\
\hline 2 & $44,45 \pm 0.45$ & 0,022 & $120.25 \pm 1.17$ \\
\hline 3 & ND & ND & $400.64 \pm 2.75$ \\
\hline 4 & $56,74 \pm 0.32$ & 0,019 & $325.90 \pm 2.75$ \\
\hline 5 & $58,24 \pm 0.30$ & 0,020 & $552.80 \pm 3.15$ \\
\hline 7 & $50,15 \pm 0.41$ & 0,018 & $736.00 \pm 5.66$ \\
\hline 8 & ND & ND & $125.00 \pm 1.75$ \\
\hline 9 & $57,49 \pm 0.35$ & 0,017 & $920.56 \pm 8.15$ \\
\hline 10 & $48,46 \pm 0.28$ & 0,001 & ND \\
\hline 11 & $52,48 \pm 0.38$ & 0,001 & ND \\
\hline Ascorbic acid $\dagger$ & $33,67 \pm 0.45$ & 0,030 & - \\
\hline Acarbose * & - & - & $85.65 \pm 1.09$ \\
\hline
\end{tabular}

Each point shows the average value of three replicates \pm SD

$N D$ (Not detected). $\dagger$ (reference of antioxidant activity); $\$$ (reference of anti diabetic activity).

$\mathrm{DPPH}$ (2, 2-diphenyl-1- picrylhydrazyl radical); $\mathrm{IC}_{50}$ (Inhibitory concentration 50).

site of action of the products tested on bacterial cells was the plasma membrane. This was directly related to the amphiphilic nature of the tested products which facilitated their insertion between the membrane phospholipids and ensured their solubilization in the lipid bilayer (Soliman et al., 2015). The good activity was attributed to the presence of pharmacologically active groups NH-CS-NH, $\mathrm{C}=\mathrm{O}$ and $\mathrm{C}=\mathrm{S}$ attached to the heterocyclic nuclei (triazoles, oxadiazoles and thiadiazoles). The presence of amine functions $\left(\mathrm{NH}_{2}\right)$ provided the tested molecules a higher activity on mushrooms than those of other products.

\subsubsection{Antioxidant activity}

From a methodological point of view, the free radical test, 2,2-diphenyl-1- picrylhydrazyl radical (DPPH) is recommended for compounds containing the $\mathrm{SH}, \mathrm{NH}$ and $\mathrm{OH}$ (Barbuceanu et al., 2014) groups and was carried out at ambient temperature. This made it possible to eliminate any risk of thermal degradation of labile molecules (Li et al., 2018). This test consisted of the reduction of an alcoholic solution of the radical species DPPH ${ }^{\bullet}$ in the presence of a hydrogen donor antioxidant (AH), which resulted in the formation of a non-radical form of DPPH-H. Based on the experimental results (see Figure 4), the starting ricinoleic triglyceride (1), ester (2) and diazoles (4, 5, 7, 9, 10 and 11) showed high activity at different concentrations. Indeed, the structure-activity relationship of the heterocycle showed that the scavenging activity of the radicals increased with the presence of the hydrogen donor groups $\left(-\mathrm{NH}_{2},-\mathrm{NH},-\mathrm{SH},-\mathrm{OH}\right)$. The conjugation between the free radicals of the hetero atoms (Nitrogen, Oxygen, Sulfur) and the $\pi$ electrons of the aromatic ring represented an additional factor to increase the stability of the radical structure.

$\mathrm{IC}_{50}$ (Inhibitory concentration 50), also referred to as $\mathrm{EC}_{50}$ (Efficient Concentration 50), is the concentration of the test sample needed to reduce $50 \%$ of the DPPH radical. The $\mathrm{IC}_{50}$ are calculated graphically by percent inhibition as a function of different concentrations of the tested product. From the value shown in Table 3, we noted a strong antiradical power for castor oil, which resulted in a fairly low $\mathrm{IC}_{50}$, comparable to that of the standard compound ascorbic acid.

\subsubsection{Hypoglycemic effect (a-amylase inhibition)}

The digestive enzyme ( $\alpha$-amylase) was responsible for hydrolyzing dietary starch (maltose), which broke down into glucose prior to absorption. The inhibition of $\alpha$-amylase led to a reduction in post prandial hyperglycemia under diabetic conditions (Yilmazer-Musa et al., 2012; Menteşe et al., 2014). $\alpha$-Amylase activity can be measured in-vitro by the hydrolysis of starch in the presence of the $\alpha$-amylases enzyme. The $\alpha$-amylase inhibitory activity was determined by using dinitro salicylic acid (DNSA). Triglyceride (1), its corresponding ester (2), synthetic products 3-11 

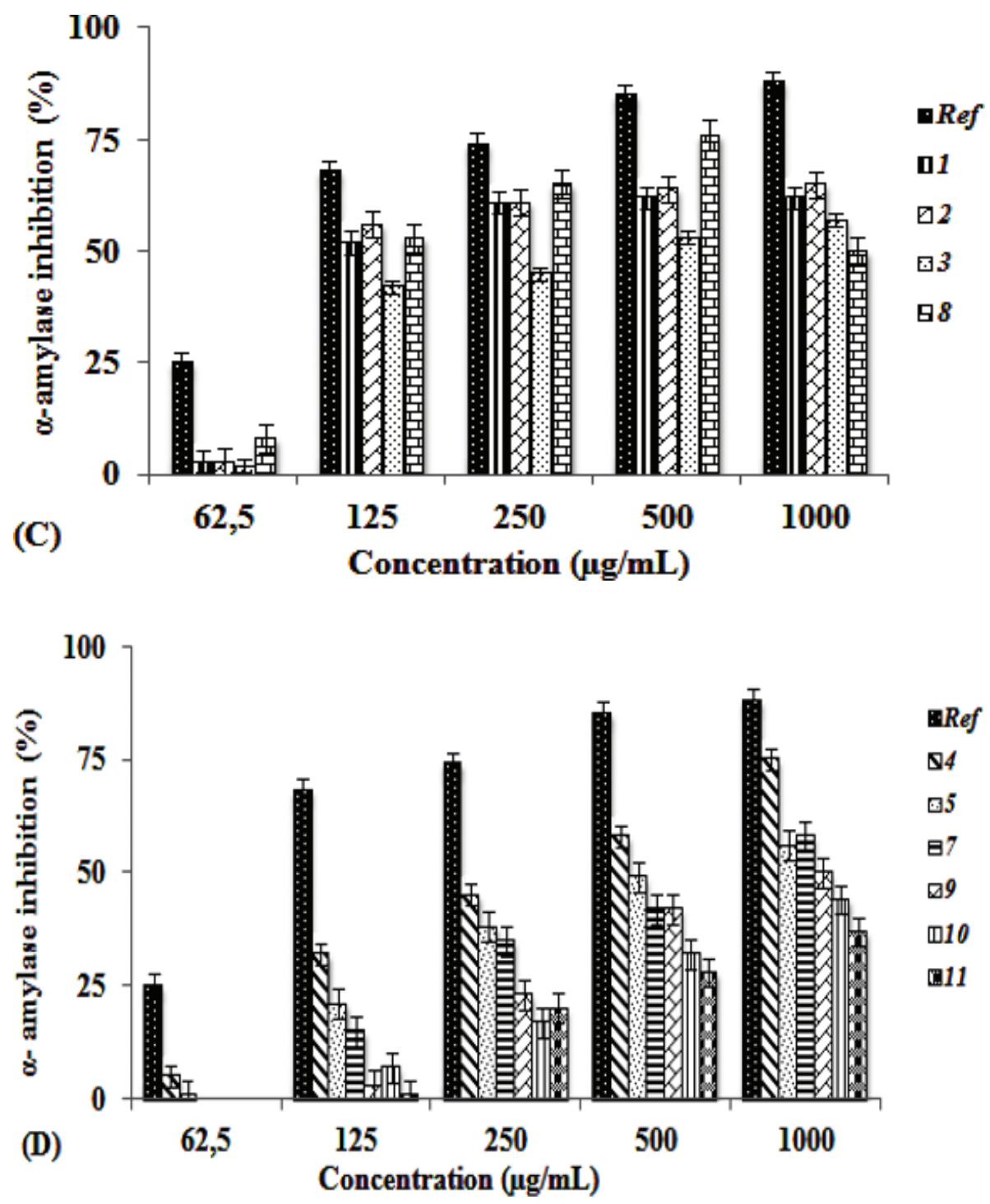

FIGURE 5. Percentage of $\alpha$ - amylase inhibition versus different concentration of:

(C) Intermediate products: Castor oil (1), Methyl ricinoleate (2), Ricinoleic acid hydrazide (3), N-Thiosemicarbazide ricinoleic (8) and Acarbose as reference. (D) Heterocyclic synthetic products: 5-Ricinoleyl-1,3,4-oxadiazole-2-thione-thiol (4), 5-Ricinoleyl-1,3,4thiadiazole-2-thione (5), 5-Ricinoleyl-4-amino-1, 2, 4-triazole-3-thiol (7), 5-Ricinoleyl-4H-1,2,4-triazole-3-thiol (9), 5-Ricinoleyl-2amino-1,3,4-oxadiazole (10), 5-Ricinoleyl-2-amino-1,3,4-thiadiazole (11) and Acarbose as reference. Each point shows the average value of three replicates \pm SD.

(except 6) and acarbose, as control, were evaluated for in vitro $\alpha$-amylase and showed a wide range of inhibitory activity (Figure 5). At a lower $\mathrm{IC}_{50}$ concentration $(\mu \mathrm{g} / \mathrm{mL})$, the above mentioned compounds were grouped into three inhibitory groups: Group A, consisting of compounds (1), (2) and (8), which exhibited an inhibition at the lowest corresponding concentrations (130.42 \pm $2.48,120.25 \pm 1.17$ and $125.00 \pm 1.75$ ) $\mu \mathrm{g} / \mathrm{mL}$ (see Table 3).

Group B, comprised of compounds (3) and (4), which showed inhibition at moderately higher concentrations $(400.64 \pm 2.75,325.90 \pm 2.75) \mu \mathrm{g} / \mathrm{mL}$.
Group C consisted of compounds (5), (7), and (9) at corresponded to the highest concentrations (552.80 $\pm 3.15,736.00 \pm 5.66,920.56 \pm 8.15) \mu \mathrm{g} / \mathrm{mL}$. Among the synthetic compounds (4), (5), (7), (9), (10) and (11), no significant inhibitory effect was detected for the heterocycles (10) and (11). Oxadiazole 4 showed the best $\alpha$-amylase inhibition.

\section{CONCLUSIONS}

The oil extract (1) (ricinoleate triglyceride) reacted over $40 \%$ from original castor oil and was closest to highest percentage reported in the literature $(45 \%)$ 
(Nakarmi et al., 2014). The synthetic compounds showed better biological effects on Gram-negative bacteria. The presence of amine functions $\left(\mathrm{NH}_{2}\right)$ of the tested molecules provided all synthesized compounds with higher activity on mushrooms. All synthesized compounds showed high antioxidant activity. The compounds with the greatest antiradical activity were noted as: Castor oil (1) $>$ Ester (2) > Amino-oxadiazole (10) > Amino-triazole (7) > Amino-thiadiazole (11) $>$ oxadiazole $(4)>$ triazole (9) $>$ thiadiazole (11). The intermediate and diazole derivatives 1-11 were evaluated for in vitro $\alpha$-amylase inhibitory activity and showed good to moderate inhibitory activity compared to standard acarbose. The synthesized compounds can be ranked in descending order of their anti-diabetic activity as follows: Acarbose $>$ Ester (2) $>$ Castor oil (1) $>$ thiosemicarbazide (8) > hydrazide (3) > oxadiazole (4) > thiadiazole (5) $>$ Amino-triazole (7) $>$ triazole (9) $>$ Aminooxadiazole (10) $>$ Amino-thiadiazole (11).

\section{CONFLICT OF INTEREST}

The authors declare no conflict of interest, financial or otherwise.

\section{REFERENCES}

Adegboye AA, Khan KM, Salar U, Aboaba SA, Chigurupati S. 2018. 2-Aryl benzimidazoles: Synthesis, In vitro $\alpha$-amylase inhibitory activity, and molecular docking study. Eur. J. Med. Chem. 150, 248-260. https://doi.org/10.1016/j. ejmech.2018.03.011

Ahmad A, Varshney H, Rauf A, Sherwani A, Owais M. 2017. Synthesis and anticancer activity of long chain substituted 1,3,4-oxadiazol-2-thione, 1,2,4- triazol-3-thione and 1,2,4-triazolo[3,4-b]-1,3,4-thiadiazine derivatives. Arab. J. Chem. 10, S3347-S3357. https://doi.org/10.1016/j.arabjc. 2014.01.015

Akhabue C, Okwundu OS. 2017. Monitoring the transesterification reaction of oil and methanol by ultraviolet visible spectroscopy. Biofuels 10, 1-8. https://doi.org/10.1080/175 97269.2017.1338128

Barbuceanu SF, Ilies DC, Saramet G. 2014. Synthesis and Antioxidant Activity: Evaluation of New Compounds from Hydrazinecarbothioamide and 1,2,4-Triazole Class Containing Diarylsulfone and 2,4-Difluorophenyl Moieties. Int. J. Mol. Sci. 15, 10908-10925. https://doi. org/10.3390/ijms150610908

Belkhadem F, Ali Othman A. 2017. Synthesis and antibacterial evaluation of new N- and S-glycosides analogues with Dinitrophenyl-Substituted heterocyclic bases. Mol. Divers. 21, 115-124. https://doi.org/10.1007/s11030-016-9704-9

Bianchi L, Pirola C, Boffito DC, Di Fronzo A, Garvoli G. 2011. Non Edible Oils: Raw Materials for sustainable Biodiesel. In Margarita S, Gisela M (Ed.). Biodiesel. Feedstocks and Processing Technologies, 978-953-307-713. https://doi. org/10.5772/1094

Cao X, Sun Z, Cao Y, Wang R, Cai T. 2014. Design, synthesis, and structured activity relationship studies of novel fused heterocyclic-linked triazoles with good activity and water solubility. J. Med. Chem. 57, 3687-3706. https://doi. org/10.1021/jm4016284

Dos Santos DS, Piovesan LA, D’Oca CR, Hack CR, Treptow TG. 2015. Antiproliferative activity of synthetic fatty acid amides from renewable resources. Bioorg. Med. Chem. 23, 340 - 347. https://doi.org/10.1016/j.bmc.2014.11.019
Dutta S, Karak N. 2005. Synthesis, characterization of poly(urethane amide) resins from Nahar seed oil for surface coating applications. Prog. Org. Coat. 53, 147-152. https://doi.org/10.1016/j.porgcoat.2005.02.003

Gad El-Karim IA, Amine MS. 2013. Fatty Acids in Heterocyclic Synthesis. Part XIV: Synthesis of Surface Active Agents from Some Novel Class of Oxadiazole, Thiadiazole and Triazole. Derivatives Having Microbiological Activities. $J$. Surfactants Deterg. 17, 509-523. https://doi.org/10.1007/ s11743-013-1530-9

Ghosh S, Tiwari S, Srivastava S. 2013. Acaricidal properties of Ricinus communis leaf extracts against organophosphate and pyrethroids resistant Rhipicephalus (Boophilus) microplus. Vet. Parasitol. 192, 259-267. https://doi.org/10.1016/j. vetpar.2012.09.031

Godard A, De caro P, Thiebaud-Roux S, Vedrenne E, Mouloungui Z. 2013. New environmentally friendly oxidative scission of oleic acid. J.A.O.C.S. 90, 133-140. https:// doi.org/10.1007/s11746-012-2134-7

Imankulov N. 2012. Preparation and research on properties of castor oil as a diesel fuel additive. Appl. Technol. Innov. 6, 30-37. https://doi.org/10.15208/ati.2012.4

Joshi D, Uttam A, Pansurya K. 2017. Synthesis and molecular modeling studies of novel pyrrole analogs as antimycobacterial agents. J. Saudl Chem. Soc. 21, 42-57. https://doi. org/10.1016/j.jscs.2013.09.002

Kumar KA, Subhash MA, Gomathi Priya G. 2017. Soxhlet extraction of Spirogyra sp. algae: an alternative fuel. Biofuels 8, 29-35. https://doi.org/10.1080/17597269.2016.1 196328

Lavanya C, Murthy IY, Nagaraj G, Mukta N. 2012. Prospects of castor (Ricinus communis L.) genotypes for biodiesel production in India. Blomass Bloenerg. 39, 204-209. https:// doi.org/10.1016/j.biombioe.2012.01.008

Li R, Ning X, Shuo Z, Lin Z, Wu X. 2018. Discovery and Structure-activity relationship of novel 4- hydroxythiazolidine-2-thione derivatives as tumor cell specific pyruvate kinase M2 activators. Eur. J. Med. Chem. 143, 48-65. https://doi.org/10.1016/j.ejmech.2017.11.023

Mentese E, Ulker S, Kahveci B. 2014. Synthesis and study of $\alpha$-glucosidase inhibitory, antimicrobial and antioxidant activities of some benzimidazole derivatives containing triazole, thiadiazole, oxadiazole, and morpholine rings. Chem. Heterocycl. Compd. 50, 12. https://doi.org/10.1007/ s10593-015-1637-1

Mubofu EB. 2016. Castor oil as a potential renewable resource for the production of functional materials. Sustain. Chem. Process. 4 (11). https://doi.org/10.1186/s40508-016-0055-8

Nakarmi A, Joshi S. 2014. A Study on Castor Oil and Its Conversion into Biodiesel by Transesterification Method. N.J.S.T. 15, 45- 52. https://doi.org/10.3126/njst.v15i1.12009

Rachapudi BNP, Bhamidipati VSK. 2017. Chemical Derivatization of Castor Oil and Their Industrial Utilization. In Moghis A (Ed.). Fatty Acids: Chemistry, Synthesis and Applications. A.O.C.S. 8, 279-303. https:// doi.org/10.1016/B978-0-12-809521-8.00008-8

Soliman H, Basuny AM. 2015. Utilisation of stearic acid extracted from olive pomace for production of triazole, thiadiazole and thiadiazines derivatives of potential biological activities. J. Oleo Sci. 9, 1019-1032. https://doi. org/10.5650/jos.ess 14261

Taieb Brahimi F, Belkadi M, Ali Othman A. 2017. Synthesis of nonionic surfactants with azoles ring bearing N- glycosides and their antibacterial activity. Arab. J. Chem. 10, 1690-1698. https://doi.org/10.1016/j.arabjc.2013.06.016

Thames SF, Yu H, Wang MD. 2006. Air-dry primer coatings from dehydrated lesquerella oil. Ind. Crops Prod. 6, 169. https://doi.org/10.1016/S0926-6690(96)00214-2

Trevino AS, Trumb DL. 2002. Aceto-acetylated castor oil in coatings applications. Prog. Org. Coat. 44, 49-54. https:// doi.org/10.1016/S0300-9440(01)00223-5

Trochain. 1930. Le Ricin. Rev. Bot. Appl. Agric. Colon . 105, 299-308. https://doi.org/10.3406/jatba.1930.4860

Vijayalaxmi S, Jayalakshmi SK, Sreeramulu K. 2015. Polyphenols from different agricultural residues: extraction, identification and their antioxidant 
12 F. Taieb Brahimi et al.

properties. J. Food Sci. Technol. 52, 2761- 2769. https:// doi.org/10.1007/s13197-014-1295-9

Witchard M. 1997. Paclobutrazol is Phloem Mobile in Castor Oil Plant (Ricinus communis L). J. Plant Growth Regul. 16, 215-217. https://doi.org/10.1007/PL00006999
Yilmazer-Musa M, Griffith AM, Michels AJ, Schneider E, Frei B. 2012. Grape Seed and Tea Extracts and Catechin 3-Gallates Are Potent Inhibitors of $\alpha$-Amylase and $\alpha$-Glucosidase Activity. J. Agric. Food Chem. 60, 8924-8929. https://doi.org/10.1021/jf301147n 